\title{
Environmental control of daily stem radius increment in the montane conifer Cedrus libani
}

\author{
Aylin Güney $^{1} \cdot$ Serkan Gülsoy $^{2}$ Özdemir Şentürk ${ }^{3} \cdot$ Armin Niessner $^{1}$ • \\ Manfred Küppers ${ }^{1}$
}

Received: 25 April 2018/Accepted: 26 August 2018/Published online: 5 June 2019

(C) The Author(s) 2019

\begin{abstract}
Growth response of conifers is species- specific and depends on site and climate conditions. Studies on daily radial stem growth use different analytical approaches to determine species reactions to environmental conditions. These results contribute to improve forecasts of tree growth under a changing climate. During 2013 and 2014, radial stem growth of 33 mature Cedrus libani individuals growing under different climatic conditions in Turkey and Germany was monitored hourly using high precision point dendrometers. Stem radius increments (SRI) were extracted from dendrometer readings. The annual course of SRI showed site-specific patterns with mean daily values ranging between 9.9 and $29.3 \mu \mathrm{m}$ over the growing season. Correlation and principal component analyses indicated that humidity and low temperatures during the growing season favored SRI. Multiple regression analyses demonstrated that precipitation and relative
\end{abstract}

Project funding: Field studies were carried out within the project funded by the German Federal Ministry of Education and Research (01DL12041) and in cooperation with the Southwest Anatolian Forest Research Institute (SAFRI) in Antalya and the Ecological Botanical Gardens (EBG) in Bayreuth.

The online version is available at http://www.springerlink.com.

Corresponding editor: Yanbo Hu.

Aylin Güney

aylinguney13@gmail.com

1 Institute of Botany, University of Hohenheim, Stuttgart, Germany

2 Faculty of Forestry, Isparta University of Applied Sciences, Isparta, Turkey

3 Gölhisar Vocational School, Burdur Mehmet Akif Ersoy University, Burdur, Turkey air humidity were the most important factors influencing daily SRI. Climate-growth relationships were further evaluated using the regression tree method. Precipitation was the most significant factor on daily SRI for all sites. The close coupling of SRI to relative air humidity and precipitation underlines the importance of stem water status for radial stem growth of $C$. libani which is native to regions with summer drought. It further explains the superior growth of $C$. libani in Germany.

Keywords CART - Climate-growth relationship . Dendrometer - Lebanon cedar · Regression tree

\section{Introduction}

Temperatures and the frequency of drought are expected to increase, especially in semi-arid and arid areas like the Mediterranean region (Stocker 2014). Changing climatic conditions might affect tree growth in a positive or negative way, and consequently influence forest productivity and species distribution (Ciais et al. 2005; Deslauriers et al. 2007b). For example, Norway spruce, Picea abies (L.) H. Karst, is susceptible to summer droughts and it is widely accepted that, in the near future in Germany, the species ability to fulfill ecological functions will decrease (Kölling et al. 2009; Milad et al. 2011). Therefore, it is important to understand how stem growth dynamics (i.e., ring formation), may be affected by environmental conditions and a changing climate (Bouriaud et al. 2005; Rathgeber et al. 2011). Automatic point or band dendrometers under high resolution are commonly used to measure variations in stem radius (Herzog et al. 1995; Deslauriers et al. 2007b). Information from dendrometer measurements allows for the investigation of the influence of site conditions and 
meteorological factors on growth, as well as speciesspecific responses to changing climate conditions (Plomion et al. 2001; Zweifel and Häsler 2001; Wimmer 2002; Michelot et al. 2012; Oberhuber et al. 2014). Vieira et al. (2013), for example, showed that growth cessation in maritime pine (Pinus pinaster Aiton) under a Mediterranean climate was influenced by water availability. Deslauriers et al. (2003) extracted daily stem radius increments (SRI) of Abies balsamea (L.) Mill. and showed how SRI was positively correlated to rainfall. However, only few studies have investigated intra-annual growth dynamics on a daily basis from the montane Mediterranean region, although the area has species which, in the future, may complement indigenous species in Central Europe with regards to climate change (Messinger et al. 2015). One of these potential species is Cedrus libani A. Rich, an evergreen conifer mainly distributed between 800 and $2000 \mathrm{~m}$ altitude along the Taurus Mountains of Turkey (Akkemik 2003; Boydak 2003). Since it has valuable timber, it is one of the most important commercial species in Turkey (Brooks et al. 2008). C. libani is light-demanding and shows good adaptability to summer droughts and temperature extremes. Because of these characteristics, it is widely used in reforestation and afforestation projects in Turkey and in other countries (Boydak 2007; Ducci et al. 2007). Messinger et al. (2015) evaluated its potential to establish viable stands in Central Europe, underlining high adaptation of $C$. libani to current and future climatic conditions. With regards to its use in forestry and its adaptability, it is important to know more about stem growth dynamics of $C$. libani under different site and climatic conditions.

During 2013 and 2014, radial stem growth was monitored along an altitudinal gradient in the Taurus Mountains of Turkey, and within a cedar plantation in Germany using high-precision point dendrometers. The objectives were: (1) to determine the influence of the environment on daily SRI during the growing season, and in this context, (2) to compare different analytical approaches. It was hypothesized that different site conditions would result in different short-term growth responses to environmental variables.

\section{Materials and methods}

\section{Study sites and data collection}

The study was conducted at five sites (four in Turkey at $1050,1355,1665$, and $1960 \mathrm{~m}$ a.s.l., and one in Germany at $360 \mathrm{~m}$ a.s.1.) under different environments during 2013 and 2014. At each site, five to nine undamaged, healthy mature $C$. libani trees were selected for continuous monitoring of radial stem changes using automatic point dendrometers (Megatron Elektronik AG \& CO, Munich, Germany; accuracy $<10 \mu \mathrm{m}$ ) (Table 1). The Turkish sites (T1-T4), were located within the Cedar Research Forest, District of Elmali, Antalya, a natural C. libani forest characterized by an oro-Mediterranean climate with cold winters and summer droughts (Senitza 1989; Basaran et al. 2008). The German site (O1) was located within a C. libani plantation established in 1980 in the Ecological-Botanical Garden of the University of Bayreuth, Bavaria, and has a subcontinental climate with cold winters and warm summers (Messinger et al. 2015). Point dendrometers were fixed to the trunks at breast height $(1.3 \mathrm{~m})$, with the outer bark carefully removed to minimize swelling and shrinking where the measuring head of the dendrometer was placed (Zweifel et al. 2006). The point dendrometers were connected to data loggers (DL2e Data logger, Delta-T devices Ltd., Cambridge, UK) which recorded radial stem changes in hourly intervals. Concurrently, air (Tair, ${ }^{\circ} \mathrm{C}$ ) and soil temperatures (Tsoil, ${ }^{\circ} \mathrm{C}$ ), precipitation $(\mathrm{Pp}, \mathrm{mm})$, soil water contents (SWC, \%), relative air humidities $(\mathrm{RH}, \%)$ and global radiation $\left(\mathrm{GR}, \mathrm{W} \mathrm{m}^{-2}\right.$ ) were determined with WatchDog 2700 Weather Stations (Spectrum Technologies Inc., Plainfield, IL, USA), or with $\mathrm{HOBO}^{\circledR}$ Pro series loggers (Onset Computer Corporation, MA, USA) at the Turkish sites. For the German site (O1) climate data was derived from the weather station located within the Ecological- Botanical Garden. Additionally, stem temperatures (Tstem) were measured with thermistors under the bark at breast height (north facing). Climate variables were measured at 10-30 min intervals and later converted to daily values. Site-specific vapor pressure deficits (VPD, hPa) were calculated from mean Tair, RH and air pressure. More detailed information on study site, study trees, and data collection is found in Güney et al. (2017).

\section{Extraction of stem radius increments (SRI)}

Daily SRI were calculated according to Downes et al. (1999) and Deslauriers et al. (2003) from raw dendrometer records and are based on stem shrinkage and swelling patterns (Deslauriers et al. 2007b). They define SRI as the third part of the stem's circadian cycle when the radius exceeds the morning maximum until the following maximum. The first part of the circadian cycle is the contraction phase (from morning maximum to daily minimum), and the second part is the expansion phase (when the same value of the morning maximum is reached). Therefore, daily SRI values were calculated as the difference between the maximum values of two consecutive days. Negative values of SRI, caused by a smaller radius maximum on the following day, were treated as zero and were included into the analysis (Deslauriers et al. 2003). Daily values of SRI were averaged for each site (Wang et al. 2015). 
Table 1 Altitude of the study sites, characteristics of the study trees and mean daily stem radius increment (SRI) during the growing season

\begin{tabular}{llllrlcl}
\hline Site & Altitude $(\mathrm{m})$ & $n^{\mathrm{a}}$ & DBH $(\mathrm{cm})$ & Height $(\mathrm{m})$ & Age $^{\mathrm{b}}($ years $)$ & SRI 2013 $^{\mathrm{c}}(\mu \mathrm{m})$ & SRI 2014 $^{\mathrm{c}}(\mu \mathrm{m})$ \\
\hline $\mathrm{T} 1$ & 1960 & 6 & $26 \pm 13$ & $8.8 \pm 2.1$ & $47 \pm 13$ & $17.5 \pm 22.9^{\mathrm{AB}}$ & $22.6 \pm 28.9^{\mathrm{AB}}$ \\
$\mathrm{T} 2$ & 1665 & 7 & $33 \pm 9$ & $20.2 \pm 1.2$ & $89 \pm 17$ & $10.3 \pm 15.2^{\mathrm{A}}$ & $12.4 \pm 17.6^{\mathrm{A}}$ \\
$\mathrm{T} 3$ & 1355 & 7 & $31 \pm 15$ & $18 \pm 6.5$ & $89 \pm 33$ & $\mathbf{9 . 9} \pm \mathbf{1 2 . 9}^{\mathbf{A}}$ & $\mathbf{1 4 . 4} \pm \mathbf{1 8 . 9 ^ { \mathrm { AB } }}$ \\
$\mathrm{T} 4$ & 1055 & 9 & $34 \pm 13$ & $14.8 \pm 3.9$ & $75 \pm 34$ & $\mathbf{1 2 . 3}^{\mathrm{B}} \pm \mathbf{1 6 . 1}^{\mathbf{A}}$ & $\mathbf{2 3 . 9} \pm \mathbf{3 2 . 1}^{\mathrm{AB}}$ \\
$\mathrm{O} 1$ & 360 & 4 & $35 \pm 4$ & $13.5 \pm 1.6$ & 35 & $29.3 \pm 39.3^{\mathrm{B}}$ & $24.1 \pm 31.4^{\mathrm{B}}$ \\
\hline
\end{tabular}

Diameter at breast height (DBH), age, height, and daily SRI are presented as means with standard deviations

Higher case capital letters indicate significant between-site differences in 2013 and 2014, Kruskal-Wallis 1 -way ANOVA, $p<0.05$ ). For more detailed information about the study sites see Güney et al. (2017)

${ }^{\mathrm{a}}$ Number of trees studied

${ }^{\mathrm{b}}$ Age at $\mathrm{DBH}$

${ }^{\mathrm{c}}$ Mean values of daily SRI during the growing period in 2013 and 2014 (significant differences between years are in bold, Wilcoxon Signed-Ranks Test $p<0.05$

\section{Climate during the 2013 and 2014 growing seasons}

For all sites, mean annual temperatures were higher in 2014 than in 2013, and exceeded the long-term mean by $0.6{ }^{\circ} \mathrm{C}$ (German site O1) and $2{ }^{\circ} \mathrm{C}$ (Turkish sites T1-T4). In 2014, total annual precipitation tended to be higher at the Turkish sites (around $300 \mathrm{~mm}$ above the long-term mean of $725 \mathrm{~mm}$ ), and lower at the German site (O1). A typical drought period was present at the Turkish sites for both years, with August and September being the hottest and driest months (Fig. 1). This also led to low soil water contents (Güney et al. 2017). At the German site (O1), July was the hottest month in both years. The site did not experience any drought although precipitation in June 2014 was exceptionally low.

\section{Statistical analysis}

To assess climatic sensitivity of daily stem radius increments, correlation coefficients were calculated between
SRI and daily environmental variables (mean air temperature Tmean, minimum air temperature Tmin and maximum air temperature Tmax, mean Tsoil, mean Tstem, Pp sum, mean SWC, mean RH, GR sum, and mean VPD). To check for normal distribution of the environmental variables, a Kolmogorov-Smirnov test was applied. Pearson's correlation coefficient was determined for normally distributed variables, and Kendall's tau correlation coefficient was determined for non-normally distributed variables (e.g., Pp). A factor analysis was first performed to avoid the problem of multicollinearity between environmental variables. Principal component analysis (PCA) was used to determine the influence of these variables on daily SRI (Oberhuber et al. 2014). Only components with eigenvalues $>1$ and percentage of variance $>10$ were considered. To assess the overall degree of variability in daily SRI explained by environmental variables, multiple stepwise regression analysis was used. Only the time period of the growing season (from April to end of September; Fig. 1) was used for analyses (Deslauriers et al. 2007b; Wang et al.
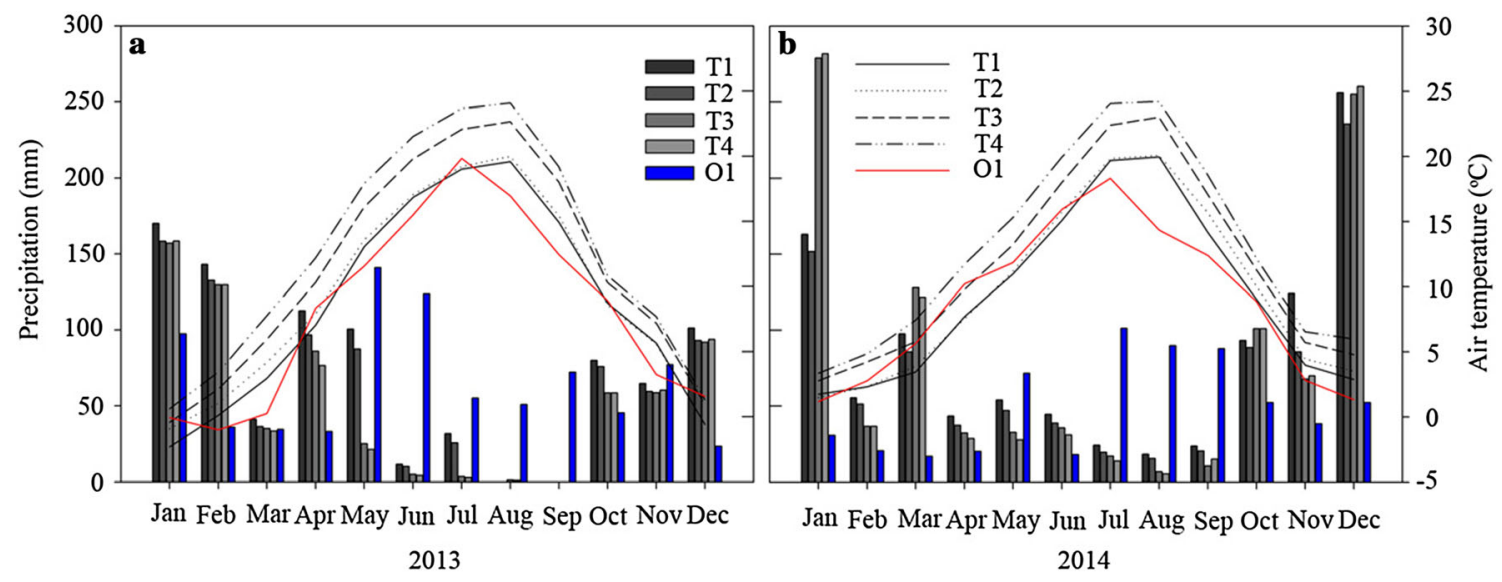

Fig. 1 Mean monthly air temperatures and precipitation recorded within the study sites during 2013 (a) and 2014 (b) 
2015). Analyses were performed for both years using SPSS v20.0 (SPSS Inc., Chicago, IL, USA) and PAST 3.16 (Wold et al. 1987) with a significance level of 0.05 .

The relationship between daily SRI (response variable) and environmental variables (predictor variables) was further analyzed using the classification and regression tree (CART). This is a non-parametric tree building technique which partitions the main data into uniform subgroups. Since our response variable is not categorical but continuous, the regression tree method was used (Breiman et al. 1984). Nodes of the regression tree indicate best split predictor variables (Özkan 2013). The earlier a predictor variable is selected as a splitter in the tree, the more important it is in the decision-making process ( $\mathrm{Xu}$ et al. 2005). Furthermore, the hierarchical structure of the regression tree allows for automatic model interactions between predictors, as the response to one input variable depends on input values higher in the tree (Aertsen et al. 2010; Cleveland et al. 2011). Regression trees were constructed using the software DTREG (Version 10.7.18). To prevent overfitting, optimal tree size was determined using pruning based on tenfold cross validation routines (Bär et al. 2008; Özkan 2013).

\section{Results}

\section{Daily SRI during the growing seasons}

Daily SRI were extracted from dendrometer records for the growing seasons 2013 and 2014 (Fig. 2). Mean daily SRI showed significant differences between the five study sites (Kruskal-Wallis test, $\chi^{2}=52.9, p>0.001$, Table 1). Significant differences between years were found for the Turkish T3 and T4 sites (Wilcoxon Signed-Ranks Test, $p>0.05$ ). During the growing seasons, mean SRI ranged between 9.9 and $29.3 \mu \mathrm{m}$ (Table 1). Highest SRI values were observed at the German O1 site, followed by the Turkish T1 (upper tree line) and T4 sites (Fig. 2). Trees of the same site showed similar courses of SRI. At all sites, longer phases of consecutive daily SRI $($ SRI $\neq 0)$ were mainly observed during periods of most linear growth (Fig. 2). A strong linear relationship $\left(\mathrm{R}^{2}=0.88\right.$, $p>0.001)$ was found between mean daily SRI during the growing season and annual tree ring width (Fig. 3). An even higher coefficient of determination $\left(\mathrm{R}^{2}=0.93\right.$, $p>0.001)$ was found for the relationship between mean daily SRI during 2 months in spring (covering the most linear growth phase for each site), and annual tree ring width.

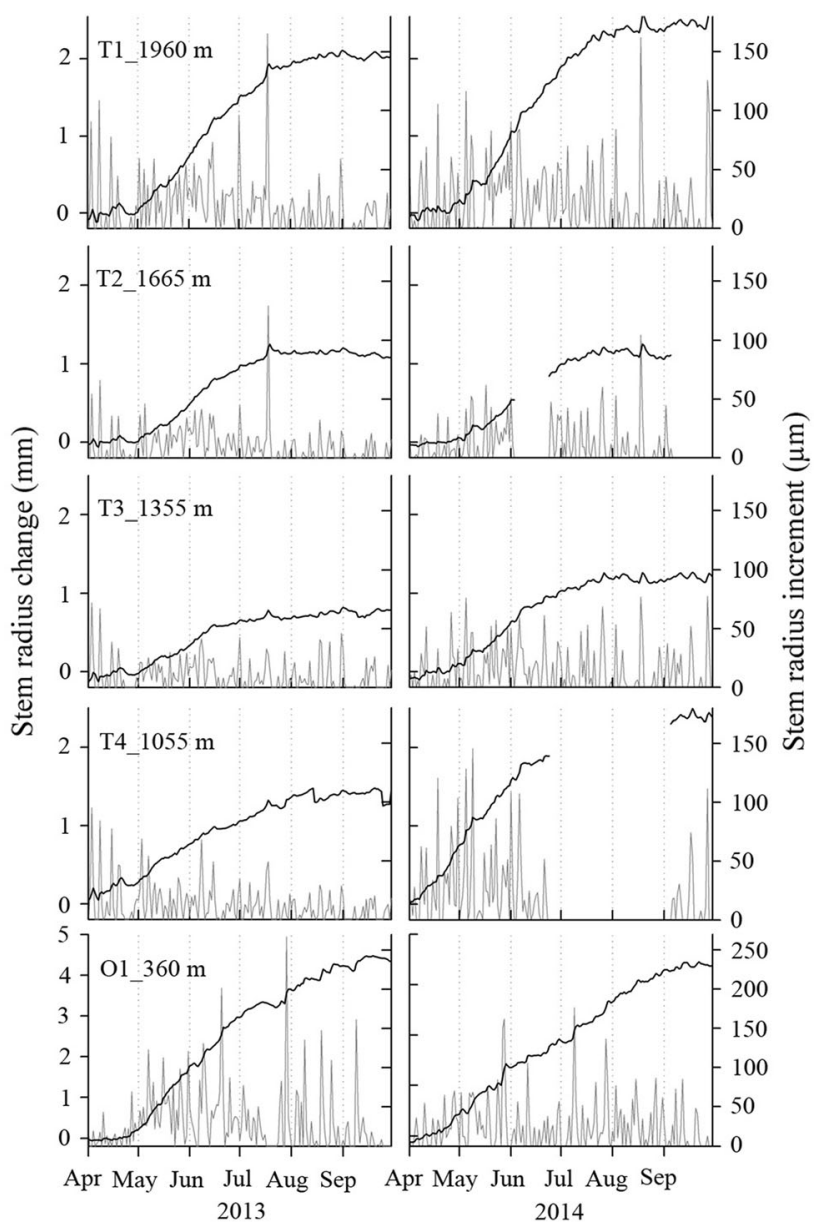

Fig. 2 Time series of measured stem radius changes by point dendrometers (Güney et al. 2017) and daily stem radius increments (SRI) at the German site (O1_360 m) and the Turkish sites (T1-T4, the four upper panel rows) during 2013 and 2014. Stem radius changes and SRI values are presented as means for each study site (mean of 4-9 individuals per site). Data gaps at $\mathrm{T} 2$ and $\mathrm{T} 4$ during 2014 are due to logger failure. Note the different scales of the y-axis between the Turkish sites (T1-T4) and the German site (O1)

\section{Relationship of daily SRI to environmental variables}

For each of the five study sites, Pearson or Kendall's tau correlation coefficients were calculated for daily SRI and ten environmental variables (Fig. 4). Correlation coefficients were calculated for each month and for the April to September growing season of both study years. At the Turkish sites (T1-T4), daily SRI showed similar responses to environmental variables. Except for Tsoil (soil temperatures), temperature variables were highly negatively correlated to SRI $(p<0.05)$ during the summer months (June to August). For the German site O1, daily SRI showed a positive correlation to Tmin during June and for the growing season. A significant positive correlation between daily SRI 


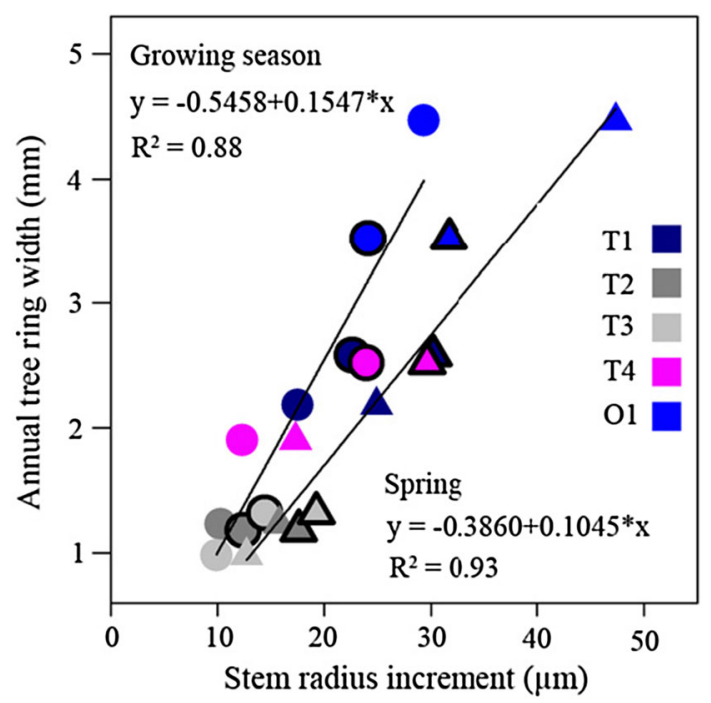

Fig. 3 Relationship between mean daily stem radius increment (SRI) and the final annual tree ring width of Cedrus libani for the five study sites. Mean daily SRI values were calculated for the growing season April to September, circles) and for a time window of 2 months covering the most linear growth phase during spring (T1-T3: May and June; T4: April and May; O1: May and June in 2013, and MidApril to Mid-June in 2014; triangles). Values from 2013 and 2014 are symbols without and with a black edge, respectively. Level of significance $p<0.001$. Values of annual tree ring width were published in Güney et al. (2017)

and SWC was found for T4 for the growing season. At all study sites, daily SRI showed close positive correlations to RH (relatively humidity) and Pp (precipitation), and significant negative correlations to GR (global radiation) and VPD (vapour pressure deficits) during the growing season. For the Turkish sites, correlation coefficients tended to decrease towards September for Pp and to increase towards August for $\mathrm{RH}$.

Correlation analysis among environmental variables showed a high correlation between Tstem, Tmean, Tmax, Tmin, and Tsoil. Results from factor analysis explained $89.9 \%$ of the variance and showed that Tmean was the most representative variable (Tmean $\mathrm{r}$ : 0.981; Tstem $\mathrm{r}$ : 0.965; Tmax r: 0.869; Tmin r: 0.867; Tsoil r: 0.816). Therefore, to avoid the problem of multicollinearity amongst these variables, only Tmean was included in further analyses.

Principal component analysis (PCA) resulted in two components with an eigenvalue greater than 1 ( $\mathrm{PC} 1$ and PC2) for all sites, explaining between 71.7 and $81.7 \%$ of the total variance (Table 2). The environmental variables for PC1 and PC2 were Tmean, Pp, SWC, RH, GR and VPD. PC1 explained 50.2 to $62.9 \%$ of the variance, while PC2 explained between 17.8 and $21.7 \%$. Regarding PC1, which has high explanatory power, daily SRI (the dependent variable) showed a close positive relationship with RH and a close negative relationship to GR and VPD at each site and for all sites. A high correlation was found between daily SRI and Pp (low angels between vectors) along both axes (see Fig. 5 for all sites). There was a negative relationship between SRI and Tmean except for the O1 and T1 sites where a shift towards axis 2 resulted in a positive correlation. SWC (soil water content) showed no significant relationship to SRI at O1 and, except for T4 (significant positive relationship along axis 1), its influence at other sites on daily SRI was marginal.

Multiple linear regression (MLR) models explained between 31 and $43 \%$ of the variation in daily SRI during the growing season (Table 3). Because of missing data due to sensor or logger failure, the number of days analyzed in the regression models varied between sites. The environmental variables GR (global radiation) and VPD (vapour pressure deficits) were not included in any of the final models. Standardized coefficients ( $\beta$ ) show that Pp and RH had the greatest influence on daily SRI at each site and for all sites. SWC was included in the MLR models of T1 and $\mathrm{T} 3$, while Tmean was included in the MLR models of T2, $\mathrm{O} 1$ and all sites, but both variables played a minor role in the models compared to $\mathrm{Pp}$ and $\mathrm{RH}$.

A strong linear relationship $\left(\mathrm{R}^{2}=0.95, p>0.001\right)$ was found between mean daily SRI of $C$. libani extracted from dendrometer measurements and modelled SRI of all sites, and for both study years ("Appendix 1"). For each site, SRI was modelled according to the results of MLR analysis (Table 3). Actual mean daily SRI and modelled SRI mostly showed a similar course ("Appendix 2", German site O1 over a time period of 3 months as an example).

Regression trees calculated for daily SRI from the data of all sites and for both growing seasons 2013 and 2014 consisted of seven terminal nodes (Fig. 6). The proportion of the variance explained $\left(\mathrm{R}^{2}\right)$ was $43.7 \%$ for the training data and $35.3 \%$ for the validation data. The predictor variables used in the splits were $\mathrm{Pp}, \mathrm{RH}$ and Tmean, among which $\mathrm{Pp}$ was the most significant environmental factor on daily SRI followed by RH. Sample days with low daily SRI are grouped at the left branch of the regression trees, and sample days with higher daily SRI are grouped at the right branch. According to the regression tree, highest daily SRI with a mean value of $127.47 \mu \mathrm{m}$ (Fig. 6, grey square, right terminal node) occur when $\mathrm{Pp}$ is more than $13.63 \mathrm{~mm}$, Tmean higher than $9.5^{\circ} \mathrm{C}$, and $\mathrm{RH}$ higher than $82.1 \%$. Lowest daily SRI with a mean value of $6.81 \mu \mathrm{m}$ (Fig. 6, light grey square, left terminal node) occur when Pp is less than $1.09 \mathrm{~mm}$ and $\mathrm{RH}$ is below $46.0 \%$. 


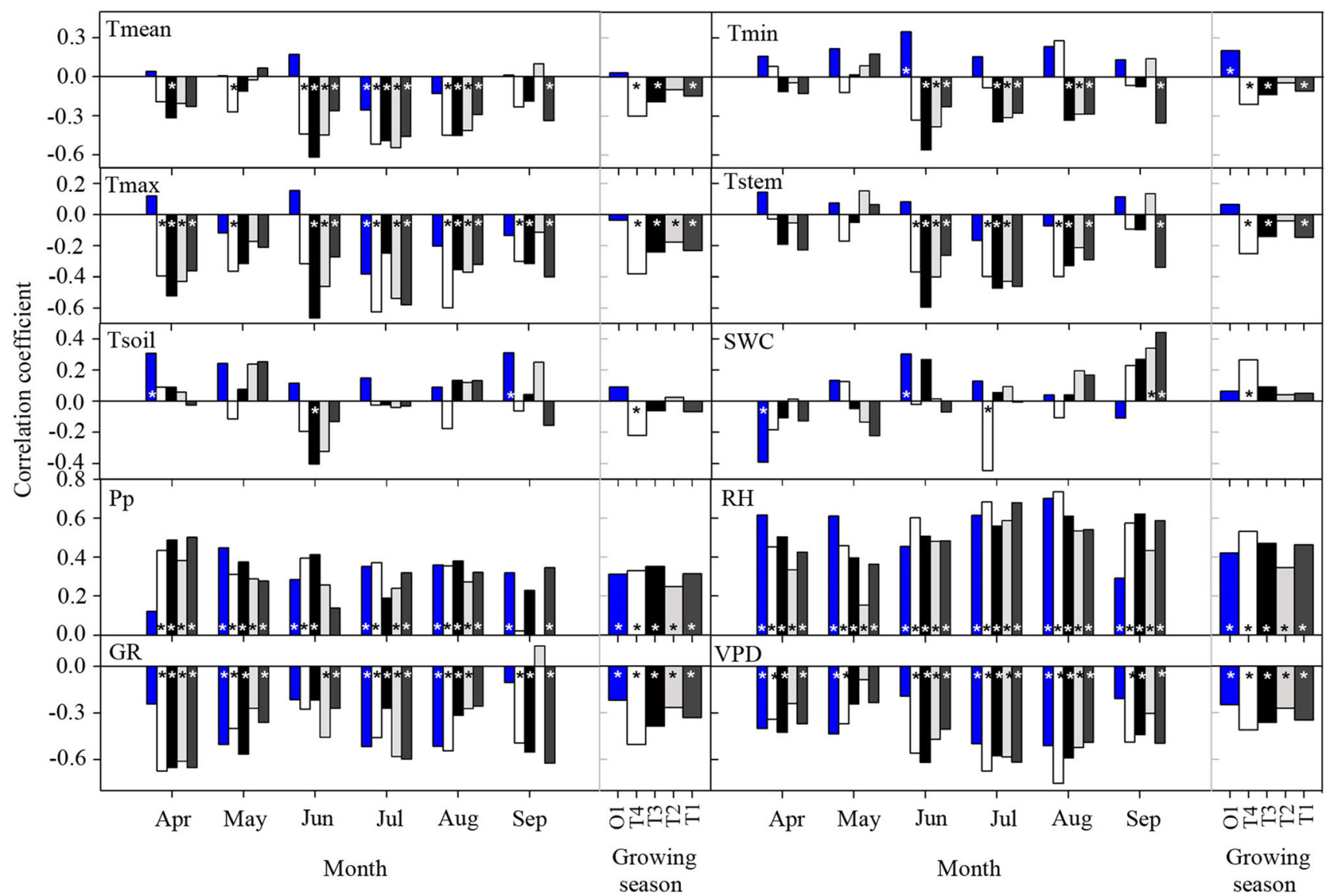

Fig. 4 Correlation coefficients between daily stem radius increments (SRI) of Cedrus libani and environmental variables: Tmean: Mean air temperature; Tmin: Minimum air temperature; Tmax: Maximum air temperature; Tstem; Stem temperature; Tsoil: Soil temperature; SWC: Soil water content; Pp: Precipitation; RH: Relative air humidity; GR: Global radiation; VPD: Vapor pressure deficit. For both study years, correlation coefficients were calculated for each

In summary, all analyses showed Pp (precipitation) and RH (relative humidity) being the most important climatic factors to positive influence daily SRI during the growing season. At all sites, the highest values of daily SRI usually coincided with peaks in RH and Pp ("Appendix 3", data from April to June as an example).

\section{Discussion}

\section{Daily SRI patterns}

Cedrus libani shows high adaptability to various climate and site conditions as it naturally occurs in the SupraMediterranean, Mountain-Mediterranean and Oro- month of the growing season separately and for the whole growing season (April to the end of September). German study site: O1 (blue bar); Turkish study sites: T4 (white bar), T3 (black bar), T2 (grey bar), T1 (dark grey bar). Pearson's correlation coefficient were calculated for Tmean, Tmin, Tmax, Tstem, Tsoil, SWC, RH, GR, and VPD. Kendall's tau coefficient was calculated for Pp. Asterisks indicate significant correlations at $p<0.05$
Mediterranean zones of the Taurus Mountains facing seaward and inner Anatolia where climatic conditions range from perhumid to humid, sub-humid and semi-arid (Sevim 1955; Kantarc1 1985; Atalay 1987; Boydak 2003). In this study, we hypothesized that $C$. libani growing under different site and climate conditions would show different growth responses to environmental variables. However, between sites there were common patterns in climategrowth relations which suggests the adaptation potential of C. libani. Similar results were found by Cocozza et al. (2016) for Picea abies in the Italian Alps at two different altitudes. Their findings show that growth responses associated with weather conditions were similar at different altitudes, but patterns of intra-annual tree ring formation (e.g., growth onset), showed altitude-specific differences. In the study by Güney et al. (2015), cambial activity and 
Table 2 Principal components' eigenvalues ( $>1)$, percentage of variance associated with each component, percentage of cumulative variance, and factor loadings of stem radius increment (SRI) of Cedrus libani and environmental variables

\begin{tabular}{llllllllllll}
\hline Site & & Eigenvalue & \% of variance & Cumulative $\%$ & SRI & Tmean & Pp & SWC & RH & GR & VPD \\
\hline O1 (360 m) & PC1 & 3.51 & 50.19 & 50.19 & -0.435 & 0.707 & -0.502 & -0.399 & -0.886 & 0.869 & 0.933 \\
& PC2 & 1.52 & 21.72 & 71.91 & 0.755 & 0.547 & 0.696 & -0.286 & 0.145 & 0.104 & 0.231 \\
T4 (1055 m) & PC1 & 4.4 & 62.88 & 62.88 & 0.62 & -0.89 & 0.605 & 0.772 & 0.92 & -0.741 & -0.93 \\
& PC2 & 1.32 & 18.83 & 81.71 & 0.608 & 0.375 & 0.641 & -0.446 & -0.069 & -0.331 & 0.288 \\
T3 (1355 m) & PC1 & 4.17 & 59.56 & 59.56 & 0.5 & -0.891 & 0.567 & 0.764 & 0.918 & -0.709 & -0.935 \\
& PC2 & 1.35 & 19.31 & 78.87 & 0.687 & 0.36 & 0.619 & -0.459 & -0.04 & -0.32 & 0.228 \\
T2 (1665 m) & PC1 & 3.83 & 54.78 & 54.78 & -0.394 & 0.862 & -0.512 & -0.689 & -0.894 & 0.733 & 0.929 \\
& PC2 & 1.32 & 18.91 & 73.69 & 0.762 & 0.355 & 0.651 & -0.346 & -0.043 & -0.181 & 0.198 \\
T1 (1960 m) & PC1 & 3.78 & 53.94 & 53.94 & -0.492 & 0.845 & -0.496 & -0.625 & -0.872 & 0.753 & 0.925 \\
& PC2 & 1.28 & 18.22 & 72.16 & 0.709 & 0.407 & 0.58 & -0.45 & 0.04 & -0.172 & 0.191 \\
All sites & PC1 & 3.77 & 53.85 & 53.85 & 0.493 & -0.781 & 0.493 & 0.732 & 0.912 & -0.685 & -0.915 \\
& PC2 & 1.25 & 17.84 & 71.69 & 0.713 & 0.365 & 0.688 & -0.276 & -0.05 & -0.069 & 0.224 \\
\hline
\end{tabular}

Tmean, Mean air temperature; Pp, Precipitation; SWC, Soil water content; RH, Relative air humidity; GR, Global radiation; VPD, Vapor pressure deficit

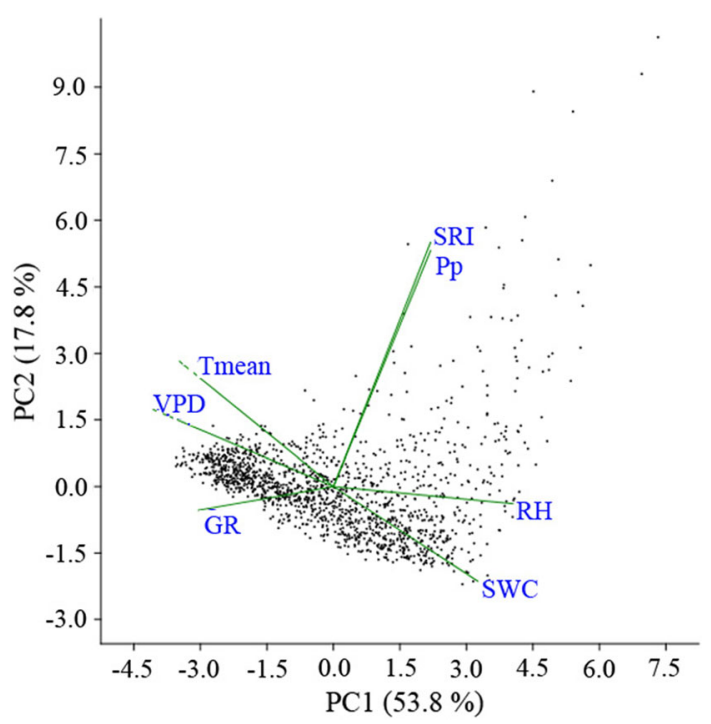

Fig. 5 Principal component analysis (PCA) of environmental factors: Tmean (mean air temperature), Pp (precipitation), SWC (soil water content), RH (relative air humidity), GR (global radiation), VPD (vapor pressure deficit) and daily SRI (stem radius increment) based on data from all sites and both study years (2013 and 2014; total number of sample days $=1517$ ). Each black dot represents one sample day xylogenesis of $C$. libani was investigated at the same sites as in this study. They found that the onset of stem growth showed an altitudinal trend with later onsets at higher altitudes, but other factors (e.g., site conditions, stand age, tree density) in addition to altitude, were responsible for final annual ring width. Since there was a direct relationship in this study between annual ring width and mean daily SRI during the growing season (the higher the SRI, the wider the annual rings, Fig. 3), an altitudinal trend for the latter was also absent. The fact that higher growth rates correspond with wider tree rings has been reported in other studies of conifer wood formation (Rathgeber et al. 2011; Cuny et al. 2012). Interestingly, the rate of daily SRI during 2 months in spring, corresponding to the period of most linear growth, explains a higher proportion of the annual ring width than the average daily SRI rate for the whole growing season. This leads to the conclusion that weather conditions prevailing during this phase are more crucial for defining final ring widths. Maximum SRI rates and average values for daily SRI for $C$. libani during the growing season were comparable to those of other conifers from high altitudes (Deslauriers et al. 2007a; Duchesne 
Table 3 Equation parameters and variance explained by environmental variables regressed on daily stem radius increments (SRI) for Cedrus libani during the growing seasons of 2013 and 2014 (April to end of September)

\begin{tabular}{|c|c|c|c|c|c|c|c|c|c|c|}
\hline \multirow[t]{2}{*}{ Site } & \multirow[t]{2}{*}{$n^{\mathrm{a}}$} & \multirow[t]{2}{*}{$\mathrm{R}^{2}$} & \multicolumn{4}{|c|}{ Environmental parameter } & \multirow[t]{2}{*}{ b0 } & \multicolumn{3}{|c|}{ Regression coefficient } \\
\hline & & & $\mathrm{Pp}$ & RH & SWC & Tmean & & b1 & b2 & b3 \\
\hline $\mathrm{T} 1$ & 341 & 0.37 & $(0.392)$ & $(\mathbf{0 . 4 3 3})$ & $(-0.216)$ & - & -8.402 & 1.787 & 0.642 & -0.700 \\
\hline $\mathrm{T} 2$ & 293 & 0.31 & $(0.415)$ & $(0.403)$ & - & $(0.279)$ & -26.625 & 1.107 & 0.415 & 0.864 \\
\hline $\mathrm{T} 3$ & 292 & 0.43 & $(0.406)$ & $(0.524)$ & $(-0.348)$ & - & -6.626 & 2.129 & 0.489 & -0.442 \\
\hline $\mathrm{T} 4$ & 225 & 0.48 & $(0.504)$ & $(0.300)$ & - & - & -11.101 & 3.635 & 0.452 & - \\
\hline $\mathrm{O} 1$ & 366 & 0.40 & $(0.478)$ & $(0.275)$ & - & $(0.166)$ & -75.911 & 3.341 & 1.042 & 1.262 \\
\hline All sites & 1517 & 0.35 & $(0.413)$ & $(0.414)$ & - & $(0.208)$ & -35.679 & 2.157 & 0.599 & 1.005 \\
\hline
\end{tabular}

The multiple linear regression analyses followed the general model: $y=b 0+b 1 \times 1+b 2 \times 2+b 3$ $\times 3$, where $\mathrm{b} 0$ is the constant. The standardized coefficient $(\beta)$, which shows the relative importance of the independent variable, is given in parentheses (the most representative variable for each model is given in bold)

For all Models and parameters the level of significance $p$ is $<0.001$

${ }^{a}$ Number of days used for the analysis (the number of days vary due to measurement gaps caused by sensor or logger failure)

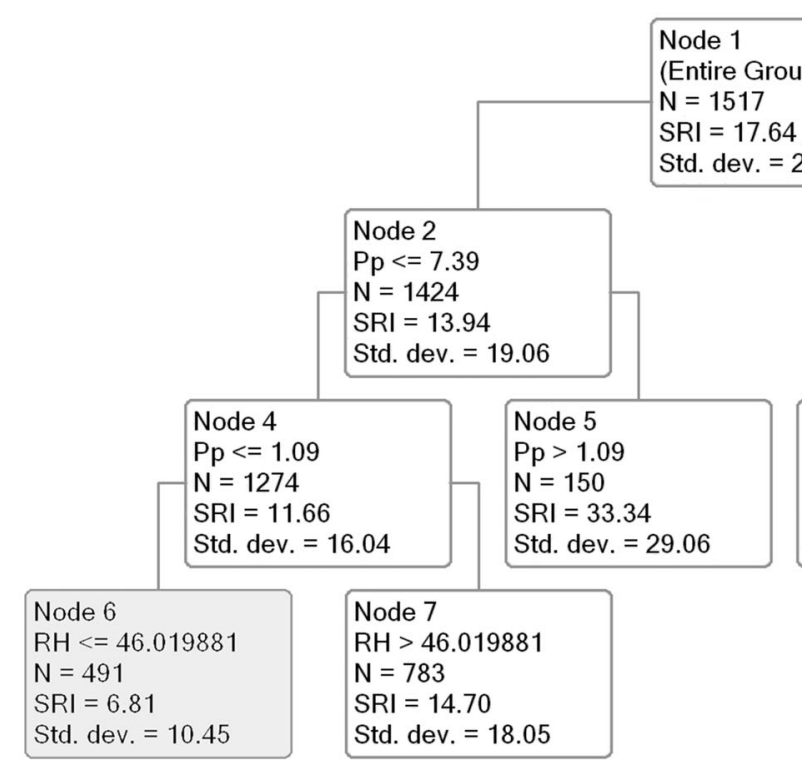

Fig. 6 Regression tree for daily stem radius increment (SRI) during the growing season (April to end of September). Regression analysis was employed using the data from all study sites and both study years (2013 and 2014; total number of sample days $=1517$ ). At the nodes, parameters with criterion values are shown. If the criterion is met,

et al. 2012; Oberhuber et al. 2014; Cocozza et al. 2016). Among our study sites, SRI rates tended to be lower on the $\mathrm{T} 2$ and $\mathrm{T} 3$ sites where mean annual ring width was also the lowest compared to the other sites (Güney et al. follow the left branch; otherwise, follow the right branch. Average daily SRI is presented with its standard deviation (SD). Highest and lowest SRIs are indicated by the grey square (right terminal node) and the light grey square (left terminal node), respectively. Pp: precipitation; RH: relative air humidity; Tmean: mean air temperature

2015 , 2017). We suggest that a generally slow growth rate allows for only a small daily SRI even when environmental conditions are favorable. 


\section{Influence of environmental factors on daily SRI using different analyses}

Studies which analyze the effect of environmental variables on daily SRI (stem radius increment) increase knowledge of tree response to short-term changes in weather conditions (Urrutia-Jalabert et al. 2015), even though biologically, tree growth does not react immediately to meteorological events (Schweingruber 1996; Deslauriers et al. 2003). Correlation analysis between SRI and environmental variables demonstrates that SRI of $C$. libani during the growing season were positively related to humidity and negatively related to high temperatures. Principal component analysis (PCA) identified the influence of environmental variables on daily SRI and permitted an insight at the multivariate level. Compared to simple correlation analysis, PCA is a more advanced method which shows bilateral correlations as a whole (Fig. 5). During the 2013 and 2014 growing seasons, daily SRI showed a strong positive relationship with RH and Pp, followed by soil water content (SWC) which played a less important role. This positive relationship of humidity on stem radius has been reported for several tree species (Deslauriers et al. 2003; Köcher et al. 2012; Oladi et al. 2017). Humid conditions have a positive effect on cell turgidity and enlargement by increasing stem water content (Steppe et al. 2015). Conversely, high temperatures and dry conditions negatively affect cell turgor, enlargement and growth (Pantin et al. 2012). The minor role of SWC on daily stem radius variations in principal component analysis (PCA) implies that transpiration primarily draws upon water stored in the stem tissues, especially on drier sites at higher altitudes. This is also supported by other researchers (Zweifel et al. 2005; Čermák et al. 2007; Betsch et al. 2011). The close coupling of SWC to SRI at the Turkish T4 site (see also the results from correlation analysis), may be due to moist conditions as a result of proximity of the Avlan Lake (Köcher et al. 2012). In addition to Pp, RH was a major positive factor affecting SRI. Dendrochronological studies on $C$. libani from the timberline of the Taurus Mountain range showed that precipitation was the most important factor favoring growth; RH was not included in these studies (Akkemik 2003; Touchan et al. 2005). Schuster and Oberhuber (2013) studied stem growth of three co-occurring conifers at $750 \mathrm{~m}$ a.s.l. in the Austrian Alps and found similar results. Based on their findings from dendrochronological studies, precipitation was found to control radial growth, while at short timescales, moist atmospheric conditions favored radial growth. They suggested that moist atmospheric conditions reduce transpiration rates, which improve water status of the trees (Oberhuber et al. 2014). At the same time, reduced transpiration rates lower the risk of stomata closure under hot and dry conditions to help maintain photosynthetic activity and promote growth (Woodruff et al. 2009; Thomas 2014). In fact, a higher correlation between relative humidity and stem radius increment in $C$. libani was present during the hottest summer months of July and August. Oladi et al. (2017) found a similar pattern in Oriental beech, as relative humidity showed a positive relation to growth during the hottest days.

The combined effects of climate on daily stem radius increment were investigated by multiple linear regression analysis and resulted in models that were dominated by precipitation and relative humidity followed by mean air temperature and soil water content. The absence of soil water content in principal component analysis and the multiple linear regression model for trees at the $\mathrm{O} 1$ site may be due to the moist conditions and uniform water supply at the German site throughout the growing season in contrast to the Turkish sites. As noted by Messinger et al. (2015), C. libani appears to adapt to climate conditions that prevail in Central Europe. Higher precipitation and relative humidity as well as lower temperatures during the growing season provide good growing conditions for $C$. libani.

To model daily stem radius increment in $C$. libani, the suitability of the CART technique was tested, a popular technique because the information is presented in a way that is easy to visualize and intuitively understood. With CART, both categorical and continuous dependent variables can be modeled (Aertsen et al. 2010; Özkan 2012). Breiman et al. (1984) developed this method which has been used in ecological studies since 1987 (Verbyla 1987). With plant ecological studies, CART is used to model distribution, diversity and productivity of plant species (McKenzie et al. 2001; McKenney and Pedlar 2003; Aertsen et al. 2010; Özkan et al. 2010). It is also used to model annual net primary productivity (Cleveland et al. 2011; Hofhansl et al. 2015). Considering tree growth, CART has been applied in dendrochronological studies (Bär et al. 2008; Koo et al. 2011; Trouvé et al. 2017) but it may never have been applied to establish models of daily radial stem increment. To extract daily stem radius increments from dendrometer records, the stem cycle approach was used (Downes et al. 1999; Deslauriers et al. 2003). Negative values were set to zero (no increment) which leads to a non-normally distributed data set. Since CART is a non-parametric method, it is suitable for application on stem radius increment (SRI) data. The regression tree modelled using data of all study sites and both years shows the interaction between environmental variables and daily SRI. The model includes the lowest and highest SRI values and presents them in a way that is easily followed. The regression tree confirmed results from preceding analysis and further underlined the positive effect of precipitation and relative humidity on daily stem radius increments of $C$. 
libani. It showed that precipitation was the most important factor on stem radius increments and that relative humidity over $46 \%$ favored radial increment (mean SRI $=14.7 \mu \mathrm{m}$ ). The fact that the daily average of relative humidity at the O1 site never dropped below 50\% during both growing seasons indicates favorable growth conditions on the site. The highest SRI rates were at the German O1 site. Consequently, drier and warmer conditions predicted during the growing season may negatively affect radial increment (Urrutia-Jalabert et al. 2015) of C. libani, particularly at drier sites (e.g., semi-arid regions of Inner Anatolia).

\section{Conclusion}

This study provides insight into the effects of the environment on daily stem radius increment of $C$. libani at different sites along an altitudinal gradient. Various analytical approaches provided similar results with precipitation and relative humidity the most important climate variables influencing stem radius increment. CART has been used to model stem radius increment and has proved to be a suitable technique. The findings underline the importance of stem water status on radial stem growth, especially in regions with summer drought. The results suggest that $C$. libani has the potential to increase stem growth at sites where moist atmospheric conditions prevail and high temperatures are absent, although other important factors (i.e., competition or light availability) affecting $C$. libani growth should not be neglected.

Acknowledgements We would like to thank to all who have contributed to this work and to the anonymous reviewers for their valuable suggestions.

Open Access This article is distributed under the terms of the Creative Commons Attribution 4.0 International License (http://crea tivecommons.org/licenses/by/4.0/), which permits unrestricted use, distribution, and reproduction in any medium, provided you give appropriate credit to the original author(s) and the source, provide a link to the Creative Commons license, and indicate if changes were made.

\section{Appendix 1}

Relationship between mean daily stem radius increment (SRI) extracted from dendrometer measurements and modelled SRI of Cedrus libani for all study sites (Turkish sites: T1-T4; German site: O1) during the 2013 (circles) and 2014 (triangles) growing season (April to end of September). For each study site, SRI was modelled according to the results of multiple regression analysis shown in Table 3 (see main article)

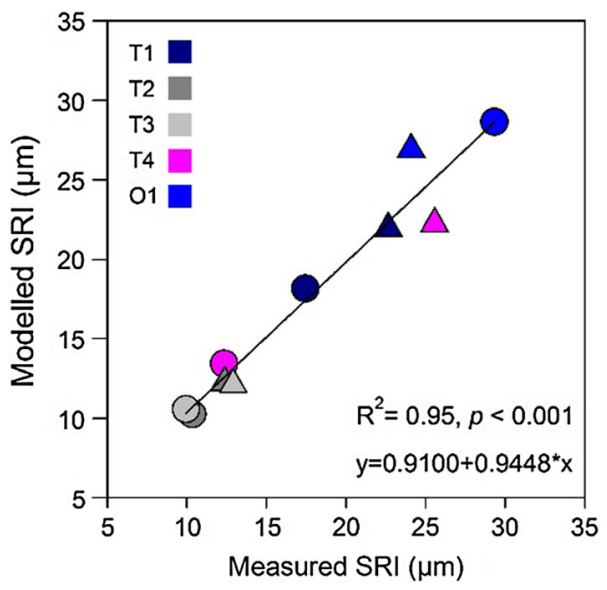

\section{Appendix 2}

Course of mean daily stem radius increment (SRI) of Cedrus libani at the German study site O1. Shown are measured SRI (black line) and modelled SRI (red line: SRI according to the model for O1; Blue line: SRI according to the model for all sites, see Table 3 of the main article) during April to end of June 2013

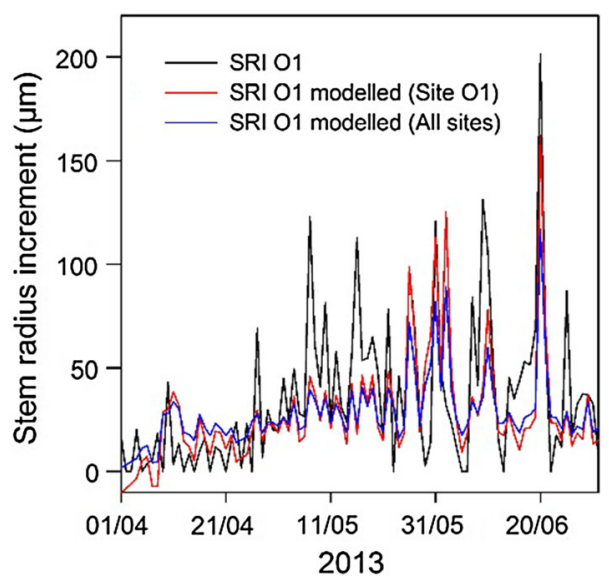




\section{Appendix 3}

Course of mean daily stem radius increment (SRI) of Cedrus libani, mean daily relative air humidity $(\mathrm{RH})$, and daily precipitation sum (Pp) at the five study sites (T1-T4: Turkish sites; O1: German site) during Spring 2013 and 2014 (April to end of June). Mean of 4-9 individuals per site. Pp data gaps at the Turkish sites due to sensor failure

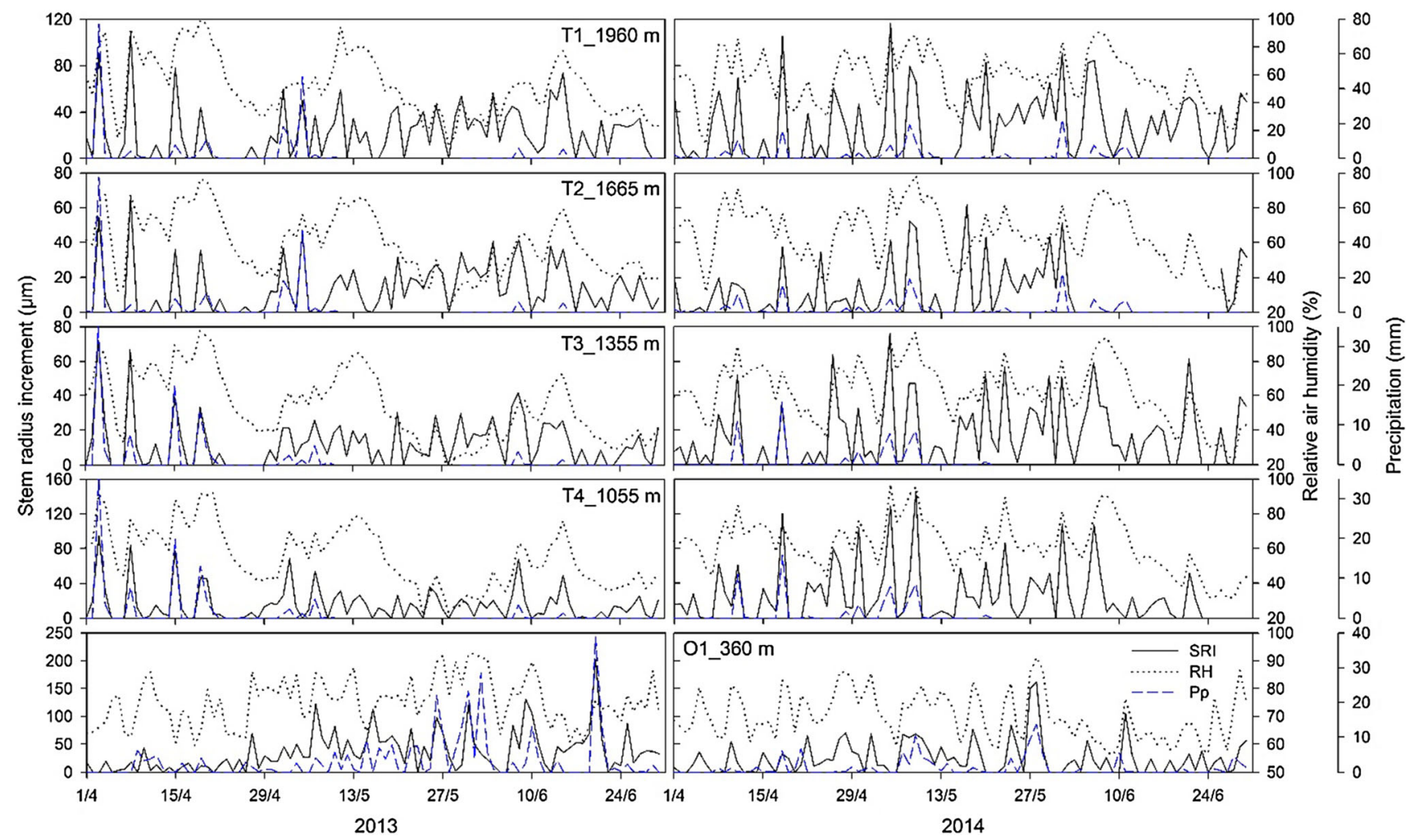

\section{References}

Aertsen W, Kint V, Van Orshoven J, Özkan K, Muys B (2010) Comparison and ranking of different modelling techniques for prediction of site index in Mediterranean mountain forests. Ecol Modell 221:1119-1130

Akkemik Ü (2003) Tree rings of Cedrus libani at the northern boundary of its natural distribution. IAWA J 24:63-73

Atalay İ (1987) Sedir (Cedrus libani A. Rich) Ormanlarının Yayılış Gösterdiği Alanlar ve Yakın Çevresinin Genel Ekolojik Özellikleri ile Sedir Tohum Transfer Rejyonlamas1 [General ecological properties of natural occurrence areas of cedar (Cedrus libani A. Rich) forests and regioning of seed transfer of cedar in Turkey. In Turkish with English summary]. Orman Genel Müdürlüğü Yayını, Ankara, p 663

Bär A, Pape R, Bräuning A, Löffler J (2008) Growth-ring variations of dwarf shrubs reflect regional climate signals in alpine environments rather than topoclimatic differences. J Biogeogr 35:625-636

Basaran MA, Basaran S, Bas N, Kaçar S, Tolunay D, Makineci E, Kavgaci A, Deniz G (2008) Determining the actual state of
Elmali cedar research forest by GIS based digital maps (in Turkish with English abstract). Çevre ve Orman Bakanlığ 1 Yayın 353:1-331

Betsch P, Bonal D, Breda N, Montpied P, Peiffer M, Tuzet A, Granier A (2011) Drought effects on water relations in beech: the contribution of exchangeable water reservoirs. Agric For Meteorol 151:531-543

Bouriaud O, Leban JM, Bert D, Deleuze C (2005) Intra-annual variations in climate influence growth and wood density of Norway spruce. Tree Physiol 25:651-660

Boydak M (2003) Regeneration of Lebanon cedar (Cedrus libani A. Rich.) on karstic lands in Turkey. For Ecol Manag 178:231-243

Boydak M (2007) Reforestation of Lebanon cedar (Cedrus libani A. Rich.) in bare karstic lands by broadcast seeding in Turkey. In: Leone V, Lovreglio R (eds) Proceedings of the international workshop MEDPINE 3: conservation, regeneration and restoration of Mediterranean pines and their ecosystems. CIHEAM, Bari, pp 33-42 (Options Méditerranéennes: Série A. Séminaires Méditerranéens; $n$. 75)

Breiman L, Friedman J, Olshen R, Stone C (1984) Classification and regression trees. Wadsworth Int Group 37(15):237-251 
Brooks JR, Jiang L, Ozçelik R (2008) Compatible stem volume and taper equations for Brutian pine, Cedar of Lebanon, and Cilicica fir in Turkey. For Ecol Manag 256:147-151

Čermák J, Kučera J, Bauerle WL, Phillips N, Hinckley TM (2007) Tree water storage and its diurnal dynamics related to sap flow and changes in stem volume in old-growth Douglas-fir trees. Tree Physiol 27:181-198

Ciais P, Reichstein M, Viovy N, Granier A, Ogee J, Allard V, Aubinet M, Buchmann N, Bernhofer C, Carrara A, Chevallier F, De Noblet N, Friend AD, Friedlingstein P, Grünwald T, Heinesch B, Keronen P, Knohl A, Krinner G, Loustau D, Manca G, Matteucci G, Miglietta F, Ourcival JM, Papale D, Pilegaard Rambal S, Seufert G, Soussana JF, Sanz MJ, Schulze ED, Vesala T, Valentini R (2005) Europe-wide reduction in primary productivity caused by the heat and drought in 2003. Nature 437:529-533

Cleveland CC, Townsend AR, Taylor P, Alvarez-Clare S, Bustamante MMC, Chuyong G, Dobrowski SZ, Grierson P, Harms KE, Houlton BZ, Marklein A, Parton W, Porder S, Reed SC, Sierra CA, Silver WL, Tanner EVJ, Wieder WR (2011) Relationships among net primary productivity, nutrients and climate in tropical rain forest: a pan-tropical analysis. Ecol Lett 14:939-947

Cocozza C, Palombo C, Tognetti R, La Porta N, Anichini M, Giovannelli A, Emiliani G (2016) Monitoring intra-annual dynamics of wood formation with microcores and dendrometers in Picea abies at two different altitudes. Tree Physiol 36:832-846

Cuny HE, Rathgeber CB, Lebourgeois F, Fortin M, Fournier M (2012) Life strategies in intra-annual dynamics of wood formation: example of three conifer species in a temperate forest in north-east France. Tree Physiol 32:612-625

Deslauriers A, Morin H, Urbinati C, Carrer M (2003) Daily weather response of balsam fir [Abies balsamea (L.) Mill.] stem radius increment from dendrometer analysis in the boreal forests of Quebec (Canada). Trees 17:477-484

Deslauriers A, Anfodillo T, Rossi S, Carraro V (2007a) Using simple causal modeling to understand how water and temperature affect daily stem radial variation in trees. Tree Physiol 27:1125-1136

Deslauriers A, Rossi S, Anfodillo T (2007b) Dendrometer and intraannual tree growth: what kind of information can be inferred? Dendrochronologia 25:113-124

Downes G, Beadle C, Worledge D (1999) Daily stem growth patterns in irrigated Eucalyptus globulus and E. nitens in relation to climate. Trees 14:102-111

Ducci F, Fusaro E, Lucci S, Ricciotti L (2007) Strategies for finalizing Conifers experimental tests to the production of improved reproductive materials. In: Proceedings of the international workshop MEDPINE3 "Conservation, regeneration and restoration of mediterranean pines and their ecosystems" (Valenzano, BA, 2005) Options Médit., Serie A, 2007, vol 75, pp 99-104

Duchesne L, Houle D, D'Orangeville L (2012) Influence of climate on seasonal patterns of stem increment of balsam fir in a boreal forest of Québec, Canada. Agric For Meteorol 162:108-114

Güney A, Kerr D, Sökücü A, Zimmermann R, Küppers M (2015) Cambial activity and xylogenesis in stems of Cedrus libani A. Rich at different altitudes. Bot Stud 56:20. https://doi.org/10. 1186/s40529-015-0100-z

Güney A, Küppers M, Rathgeber C, Şahin M, Zimmermann R (2017) Intra-annual stem growth dynamics of Lebanon Cedar along climatic gradients. Trees 31:587-606

Herzog KM, Häsler R, Thum R (1995) Diurnal changes in the radius of a subalpine Norway spruce stem: their relation to the sap flow and their use to estimate transpiration. Trees 10:94-101

Hofhansl F, Schnecker J, Singer G, Wanek W (2015) New insights into mechanisms driving carbon allocation in tropical forests. New Phytol 205:137-146
Kantarcı MD (1985) Dibek (Kumluca) ve Çamkuyusu (Elmalı) Sedir (Cedrus libani A. Richard) Ormanlarında Ekolojik araştırmalar. İstanbul Üniversitesi Orman Fakültesi Dergisi A 35:19-36

Köcher P, Horna V, Leuschner C (2012) Environmental control of daily stem growth patterns in five temperate broad-leaved tree species. Tree Physiol 32:1021-1032

Kölling C, Knoke T, Schall P, Ammer C (2009) Überlegungen zum Risiko des Fichtenanbaus in Deutschland vor dem Hintergrund des Klimawandels. Forstarchiv 80:42-54

Koo K-A, Patten BC, Creed IF (2011) Picea rubens growth at high versus low elevations in the Great Smoky Mountains National Park: evaluation by systems modeling. Can J For Res 41:945-962

McKenney DW, Pedlar JH (2003) Spatial models of site index based on climate and soil properties for two boreal tree species in Ontario, Canada. For Ecol Manag 175:497-507

McKenzie D, Hessl AE, Peterson DL (2001) Recent growth of conifer species of western North America: assessing spatial patterns of radial growth trends. Can J For Res 31:526-538

Messinger J, Güney A, Zimmermann R, Ganser B, Bachmann M, Remmele S, Aas G (2015) Cedrus libani: a promising tree species for Central European forestry facing climate change? Eur J For Res 134:1005-1017

Michelot A, Simard S, Rathgeber C, Dufrene E, Damesin C (2012) Comparing the intra-annual wood formation of three European species (Fagus sylvatica, Quercus petraea and Pinus sylvestris) as related to leaf phenology and non-structural carbohydrate dynamics. Tree Physiol 32:1033-1045

Milad M, Schaich H, Bürgi M, Konold W (2011) Climate change and nature conservation in Central European forests: a review of consequences, concepts and challenges. For Ecol Manag 261:829-843

Oberhuber W, Gruber A, Kofler W, Swidrak I (2014) Radial stem growth in response to microclimate and soil moisture in a drought-prone mixed coniferous forest at an inner Alpine site. Eur J For Res 133:467-479

Oladi R, Elzami E, Pourtahmasi K, Bräuning A (2017) Weather factors controlling growth of Oriental beech are on the turn over the growing season. Eur J For Res 136:345-356

Özkan K (2012) Sınıflandırma ve regresyon ağacı tekniği (SRAT) ile ekolojik verinin modellenmesi. SDÜ Orman Fakültesi Dergisi $13: 1-4$

Özkan K (2013) Using the non-parametric classifier CART to model Lebanon Cedar (Cedrus libani A. Rich) distribution in a Mountain Mediterranean Forest District. Pol J Environ Stud 22(2):495-501

Özkan K, Gulsoy S, Aerts R, Muys B (2010) Site properties for Crimean juniper (Juniperus excelsa) in semi-natural forests of south western Anatolia, Turkey. J Environ Biol $31: 97-100$

Pantin F, Simonneau T, Muller B (2012) Coming of leaf age: control of growth by hydraulics and metabolics during leaf ontogeny. New Phytol 196:349-366

Plomion C, Leprovost G, Stokes A (2001) Wood formation in trees. Plant Physiol 127:1513-1523

Rathgeber CBK, Longuetaud F, Mothe F, Cuny H, Le Moguédec G (2011) Phenology of wood formation: data processing, analysis and visualisation using R (package CAVIAR). Dendrochronologia 29:139-149

Schuster R, Oberhuber W (2013) Drought sensitivity of three cooccurring conifers within a dry inner Alpine environment. Trees 27:61-69

Schweingruber FH (1996) Tree rings and environment: dendroecology. Paul Haupt Publishers, Bern, p 609 
Senitza E (1989) Waldbauliche Grundlagen der Libanonzeder $(\mathrm{Ce}$ drus libani A. Rich) im Westtaurus/Türkei. Dissertation (in German). VWGO Publisher, Vienna, Austria, p 225

Sevim M (1955) Lübnan Sedirinin (Cedrus libani) Türkiye'deki tabii yayılış ve ekolojik şartları. İstanbul Üniversitesi Orman Fakültesi Dergisi 2(2):19-46 (in Turkish)

Steppe K, Sterck F, Deslauriers A (2015) Diel growth dynamics in tree stems: linking anatomy and ecophysiology. Trends Plant Sci 20:335-343

Stocker TF (2014) Climate change 2013: the physical science basis. Working group I contribution to the fifth assessment report of the intergovernmental panel on climate change. Cambridge University Press, Cambridge, p 1535

Thomas PA (2014) Trees: their natural history. Cambridge University Press, Cambridge, p 286

Touchan R, Xoplaki E, Funhauser G, Luterbacher J, Hughes MK, Erkan N, Akkemik Ü, Stephan J (2005) Reconstructions of spring/summer precipitation for the Eastern Mediterranean from tree-ring widths and its connection to large-scale atmospheric circulation. Clim Dyn 25:75-98

Trouvé R, Bontemps JD, Collet C, Seynave I, Lebourgeois F (2017) Radial growth resilience of sessile oak after drought is affected by site water status, stand density, and social status. Trees 31:517-529

Urrutia-Jalabert R, Rossi S, Deslauriers A, Malhi Y, Lara A (2015) Environmental correlates of stem radius change in the endangered Fitzroya cupressoides forests of southern Chile. Agric For Meteorol 200:209-221

Verbyla DL (1987) Classification trees: a new discrimination tool. Can J For Res 17:1150-1152
Vieira J, Rossi S, Campelo F, Freitas H, Nabais C (2013) Seasonal and daily cycles of stem radial variation of Pinus pinaster in a drought-prone environment. Agric For Meteorol 180:173-181

Wang Z, Yang B, Deslauriers A, Bräuning A (2015) Intra-annual stem radial increment response of Qilian juniper to temperature and precipitation along an altitudinal gradient in northwestern China. Trees 29:25-34

Wimmer R (2002) Wood anatomical features in tree-rings as indicators of environmental change. Dendrochronologia 20:21-36

Wold S, Esbensen K, Geladi P (1987) Principal component analysis. Chemometr Intell Lab Syst 2:37-52

Woodruff D, Meinzer F, Lachenbruch B, Johnson D (2009) Coordination of leaf structure and gas exchange along a height gradient in a tall conifer. Tree Physiol 29:261-272

Xu M, Watanachaturaporn P, Varshney PK, Arora MK (2005) Decision tree regression for soft classification of remote sensing data. Remote Sens Environ 97:322-336

Zweifel R, Häsler R (2001) Link between diurnal stem radius changes and tree water relations. Tree Physiol 21:869-877

Zweifel R, Zimmermann L, Newbery D (2005) Modeling tree water deficit from microclimate: an approach to quantifying drought stress. Tree Physiol 25:147-156

Zweifel R, Zimmermann L, Zeugin F, Newbery DM (2006) Intraannual radial growth and water relations of trees: implications towards a growth mechanism. J Exp Bot 57:1445-1459

Publisher's Note Springer Nature remains neutral with regard to jurisdictional claims in published maps and institutional affiliations. 